\title{
Serum Levels of Antioxidant Vitamins (Vitamin A, C, E) and Magnesium in Children With Allergic Rhinitis
}

\author{
Allerjik Rinitli Çocuklarda Antioksidan Vitaminler (Vitamin A, C, E) ve Magnezyum Düzeyleri
}

\author{
Recep SANCAK \\ Department of Pediatrics, Medical Faculty of Ondokuz Mayıs University, Samsun
}

Submitted / Başvuru tarihi: 25.09.2008 Accepted / Kabul tarihi: 21.11.2008

\begin{abstract}
Objectives: The aim of the study is to measure the levels of antioxidant vitamins and magnesium during allergic rhinitis attacks.
\end{abstract}

Patients and Methods: Thirty five children who have sensitivity for house dust and mite with mild/ moderate persistent allergic rhinitis without any other allergic diseases were considered as the study group, and 35 healthy children as the control group. The patient group was classified according to the symptom scoring system. Venous blood samples were obtained before breakfast in each group to determine serum vitamin $A, C, E$ and magnesium levels.

Results: Serum vitamin A level was significantly lower in the study group compared with the control group. However, there was no statistically significant difference between the groups in terms of serum vitamin $\mathrm{C}, \mathrm{E}$ and magnesium levels.

Conclusion: This study showed that vitamin A consumption increases to repair mucosal epithelium which is damaged by inflammation and to prevent the oxidative damage in allergic rhinitis. This result may imply new therapeutic approaches. Key words: Allergic rhinitis; vitamin A; vitamin E; vitamin $C$; magnesium; oxidative stress; free radicals; child.
Amaç: Bu çalışmada allerjik rinit atakları esnasında antioksidan vitaminler ve magnezyum düzeylerinin ölçümü amaçlanmıştır.

Hastalar ve Yöntemler: Çalışmaya orta persistan allerjik rinit tanısı konulan, diğer allerjik hastalıkları olmayan ve cilt testinde ev tozu akarlarına karşı hassasiyeti saptanan 35 hasta çalışma grubu, 35 sağlıklı çocuk kontrol grubu olarak alındı. Hasta grubu semptom skorlama sistemine göre sınıflandırıldı. Serum vitamin A, C, $E$ ve magnezyum seviyelerini ölçmek için venöz kan örnekleri her grup için sabah kahvaltıdan önce alındı.

Bulgular: Alerjik rinitli çocuklarda serum vitamin $\mathrm{A}$ düzeyi kontrol grubuna göre belirgin olarak düşük bulundu. Gruplar arasında serum vitamin C, E ve magnezyum seviyelerinde istatistiksel olarak anlamlı fark yoktu.

Sonuç: Bu çalışmada, alerjik rinitte oksidatif harabiyeti önlemek ve inlamasyonla harap edilen mukozal epiteli tamir etmek için vitamin A'nın tüketildiği düşünülmektedir. Bu sonuç aynı zamanda da yeni tedavi yaklaşımlarını akla getirmektedir.

Anahtar sözcükler: Allerjik rinit; vitamin A; vitamin E; vitamin C; magnezyum; oksidatif stres; serbest radikaller; çocuklar.

Presented at the 14th National Congress of Allergy and Clinical Immunology, November 4-8, 2006, Antalya, Turkey (14. Ulusal Alerji ve Klinik Immünoloji Kongresi'nde sunulmuştur, 4-8 Kasım 2006, Antalya).

Correspondence (Illetişim adresi): Dr. Recep Sancak. Ondokuz Mayıs Üniversitesi Tıp Fakültesi Çocuk Sağlığı ve Hastalıkları Anabilim Dalı, 55139 Samsun. Tel: 0362 - 3121919 /2498 Fax (Faks): 0362 - 4576041 e-mail (e-posta): sancakrec@yahoo.com

(c) Trakya Üniversitesi Tıp Fakültesi Dergisi. Ekin Tıbbi Yayıncıık tarafından basılımışır. Her hakkı sakııır.

(c) Medical Journal of Trakya University. Published by Ekin Medical Publishing. All rights reserved. 
As a common health problem, allergic rhinitis (AR) does not cause any mortality. However, the life quality, productivity at work, and achievements at school get decreased because of the morbidity which is formed by AR. ${ }^{[1]}$ Allergic rhinitis is an inflammatory illness which is formed through the medium of IgE of nasal mucosa. ${ }^{[1,2]}$ During the inflammation process, reactive oxygen substances which are harmful for tissues are released from the eosinophil, neutrophil and macrophages. These toxic metabolites damage epithelium cells which prevent the nasal mucosa against the allergens and microorganisms. Therefore, the ciliary malfunction occurs by generating oxidative stress. ${ }^{[3]}$ Thus, the clinic symptoms get worse and treatment process takes longer time.

There are different enzymatic and non-enzymatic antioxidant defense systems in the body to prevent and limit the oxidative damages in cells and tissues by reactive oxygen radicals. Non-enzymatic defense systems include albumin, ferritin and vitamins A, C, E. ${ }^{[4-6]}$ During this oxidative stress process, a reduction on serum levels is expected due to the consumption of these antioxidant materials. In the literature, there are few studies on serum levels of serum antioxidants of allergic illness. Those studies are especially on asthma and atopic dermatitis.

Allergic rhinitis is a common illness which can be seen in children and adults, however there is no study illustrating the relationship between antioxidant vitamin levels and AR. In this study, the main goal is to investigate antioxidant vitamins and magnesium $(\mathrm{Mg})$ levels during moderate persistent rhinitis attacks in children with AR.

\section{PATIENTS AND METHODS}

Thirty-five patients aged between 6-17, who came to the allergy clinic between January 2005 and June 2006, were included. They had no other allergic diseases except medium persistent allergic rhinitis diagnosed by the physical and history examination.

The control group includes 35 healthy children who have no allergic or chronic disease. The control and allergic groups' age and sex were matched. The attention was paid to the point that children in the study and control group had no malnutrition and growing problems, and also took no vitamin and drugs. Those who had sensitivity to house dust were included in the study group. Body mass indexes and other anthropometric measurements were recorded.

Anthropometric measurements, risk factors for allergic rhinitis and socio-demographic features of the both groups were questioned. In the study group, nasal symptoms were scored and the results were recorded.

Blood samples were collected in the morning before breakfast and prior to any medication. After centrifugation, the obtained serum was stored in $-20^{\circ} \mathrm{C}$ and protected from any source of light. Vitamin $\mathrm{A}, \mathrm{C}$ and $\mathrm{E}$ levels were determined using dedicated reagents and columns for high performance liquid chromatography analysis by Chromsystems Instruments \& Chemicals $\mathrm{GmbH}$, München, Germany. Analyses were performed with UV detector (HP 1100, Agilen Technologies). The parameters for vitamin A and $\mathrm{E}$ analysis were $50 \mu \mathrm{l}$ injection volume, $1.5 \mathrm{ml} /$ min flow rate, room temperature $25^{\circ} \mathrm{C}$, detection at a wavelength of $325 \mathrm{~nm}$ for vitamin A and $295 \mathrm{~nm}$ for vitamin E; for vitamin C: $20 \mu 1$ injection volume, 1.3 $\mathrm{ml} / \mathrm{min}$ flow rate, room temperature $25^{\circ} \mathrm{C}$, detection at a wavelength of $245 \mathrm{~nm}$.

For the determination of $\mathrm{Mg}$ level, serum was separated from clotted blood and stored in acid-washed tubes in $-20^{\circ} \mathrm{C}$ until analysis by Cobas Integre 800 Autoanalyzer with dedicated reagent Magnesium Roche, Diagnostics, GmbH, Mannheim, Germany. The samples were diluted with deionized water for the determination of Mg. Calibration standards were prepared with deionized water in the concentration ranges of $0.1-0.5 \mathrm{mg} /$ $\mathrm{dl}$ for $\mathrm{Mg}$. Reading for $\mathrm{Mg}$ was performed against $\mathrm{Mg}$ standards at wavelengths of $285.2 \mathrm{~nm}$.

\section{Statistical Analysis}

SPSS software package for Windows ${ }^{\circledR}$ (version 10.5) was used for statistical analysis. Descriptive statistics were provided for the numeric and categorical variables using means, standard deviation and percentage distribution where necessary. Student's t-test was used to investigate the statistical significance of the differences between the vitamins and $\mathrm{Mg}$ concentrations determined in the patients and in the control group. To compare the data chi-square test was used. The criterion for significance was set at $\mathrm{p}<0.05$.

\section{RESULTS}

The ages of the study and control groups were 133.2 \pm 41.7 and 147.6 \pm 37.8 months, respectively. There was no statistically significant difference between groups. There was no difference in birth weight of children between the groups. The number of individuals and sibling in family was $5.7 \pm 1.3$ and $2.5 \pm 0.9$, respectively in the study group, and $5.8 \pm 1.3 ; 2.7 \pm 1.3$, respectively in the control group. There was no significant difference between the groups with regard to breastfeeding. Although the height, weight, body mass index, height versus weight were in a quite normal range, there was no statistically significant difference from anthropometric measurement point of view between the groups $(p>0.05)$. There was no difference on environmental characteristics and parental socio-demographic features except parental education level and allergic illness situation. All of the results are shown at Table I. 
Serum Levels of Antioxidant Vitamins (Vitamin A, C, E) and Magnesium in Children With Allergic Rhinitis

Table 1. The characteristics of the study and control groups

\begin{tabular}{|c|c|c|c|c|c|}
\hline & Study group $(n=35)$ & Control group $(\mathrm{n}=35)$ & $t$ & $\chi^{2}$ & $p$ \\
\hline Age (months) & $133.20 \pm 41.36$ & $147.57 \pm 37.78$ & 1.52 & & $>0.05$ \\
\hline Height (cm) & $145.00 \pm 20.71$ & $149.31 \pm 18.37$ & 0.92 & & $>0.05$ \\
\hline Weight (kg) & $40.54 \pm 16.69$ & $42.51 \pm 13.34$ & 0.54 & & $>0.05$ \\
\hline Body mass index $\left(\mathrm{kg} / \mathrm{m}^{2}\right)$ & $18.39 \pm 2.71$ & $18.43 \pm 2.30$ & 0.07 & & $>0.05$ \\
\hline \multicolumn{6}{|l|}{ Sex } \\
\hline Female (n; \%) & $16(45.7 \%)$ & $20(57.1 \%)$ & & 0.92 & $>0.05$ \\
\hline Male (n; \%) & $19(54.3 \%)$ & $15(42.9 \%)$ & & & \\
\hline \multicolumn{6}{|l|}{ Birth-weight (gr) } \\
\hline$>2500(\mathrm{n} ; \%)$ & $33(94.3 \%)$ & $34(97.1 \%)$ & & 0.35 & $>0.05$ \\
\hline$<2500(\mathrm{n} ; \%)$ & $2(94.3 \%)$ & $1(97.1 \%)$ & & & \\
\hline \multicolumn{6}{|l|}{ Breastfeeding (months) } \\
\hline$\geq 6(\mathrm{n} ; \%)$ & $28(80.0 \%)$ & $23(65.7 \%)$ & & 1.81 & $>0.05$ \\
\hline$<6(\mathrm{n} ; \%)$ & $7(20.0 \%)$ & $12(34.3 \%)$ & & & \\
\hline \multicolumn{6}{|l|}{ Allergic parents } \\
\hline Yes $(\mathrm{n} ; \%)$ & $26(74.3 \%)$ & $4(11.4 \%)$ & & 28.23 & $<0.05$ \\
\hline No $(n ; \%)$ & $9(25.7 \%)$ & $31(88.6 \%)$ & & & \\
\hline \multicolumn{6}{|l|}{ Smoking at home } \\
\hline Yes $(\mathrm{n} ; \%)$ & $16(45.7 \%)$ & $20(57.1 \%)$ & & 0.92 & $>0.05$ \\
\hline No $(n ; \%)$ & $19(54.3 \%)$ & $15(42.9 \%)$ & & & \\
\hline
\end{tabular}

*Student's $\mathrm{t}$ test and chi-square were used for the data analysis.

The serum antioxidant vitamins and magnesium values of both study and control groups are shown in Table II. The vitamin A serum levels of the study and control groups were $1.21 \pm 0.37$ (range: $0.50-1.90$ ) and $1.53 \pm 0.39$ (range: $0.56-2.37) \mu \mathrm{mol} / \mathrm{L}$, respectively. The vitamin A serum level of the study group was significantly lower than the control group $(p<0.05)$. Serum vitamin $C$ level of study group and control group were $10.21 \pm 2.82 \mathrm{mg} / \mathrm{L}$ (5.08-14.91) and 9.61 $\pm 2.61(4.62-14.96) \mathrm{mg} / \mathrm{L}$ respectively. Although the vitamin $\mathrm{C}$ level of control group was lower than the study group, there was no statistically significant difference $(p>0.05)$. Serum vitamin E level of allergic rhinitis group and control group were 22.28 \pm 7.14 $\mu \mathrm{mol} / \mathrm{L}$ (5.60-33.09) and 25.83 $\pm 8.51 \mu \mathrm{mol} / \mathrm{L}(10.16-47.11)$ respectively. Although the vitamin E level was lower in AR group, there was no statistically significant difference $(\mathrm{p}<0.05)$.

Serum $\mathrm{Mg}$ levels in the study and control groups were $0.82 \pm 0.05 \mathrm{mmol} / \mathrm{L}(0.72-0.94)$ and $0.84 \pm 0.05$ $\mathrm{mmol} / \mathrm{L}(0.70-0.94)$, respectively. There was no statistically significant difference between the groups.

\section{DISCUSSION}

Allergic rhinitis is an inflammatory illness which affects the nasal mucosa. ${ }^{[2,7]}$ Mostly, it is generated with other inflammatory respiratory tract illnesses such as asthma, sinusitis, otitis media. ${ }^{[2,7,8]}$ This study includes only the patients who applied with nasal symptoms and diagnosed as allergic rhinitis. The demographic characteristics such as age, sex, environmental and parental structure of the study and control groups were examined for evaluated risk factors of allergic disease.

Oxidative stress is one of the main determinant of inflammation and inflammatory diseases. Antioxidant systems get activated in case of oxidant attacks. Normally, there is a balance between oxidative stress and antioxidants. Any change in the balance of them cause an AR attack. ${ }^{[9,10]}$ One of the main objectives of our study is to define serum levels in systemic circulation of antioxidants during mid persistent AR attack. For the purpose, antioxidant vitamins (vitamin A, C, E) and magnesium levels have been assessed. In literature,

Table 2. Serum levels of antioxidant vitamins (Vitamin A, C and E) and magnesium

\begin{tabular}{lcccc}
\hline Biochemical values & $\begin{array}{c}\text { Study group } \\
(\mathrm{n}=35)\end{array}$ & $\begin{array}{c}\text { Control group } \\
(\mathrm{n}=35)\end{array}$ & $t$ & $p$ \\
\hline Vitamin A $(\mu \mathrm{mol} / \mathrm{L})$ & $1.21 \pm 0.37$ & $1.53 \pm 0.39$ & 3.52 & $<0.05$ \\
Vitamin C $(\mathrm{mg} / \mathrm{L})$ & $10.21 \pm 2.82$ & $9.61 \pm 2.61$ & -0.92 & $>0.05$ \\
Vitamin E $(\mu \mathrm{mol} / \mathrm{L})$ & $22.28 \pm 7.14$ & $25.83 \pm 8.51$ & 1.89 & $>0.05$ \\
Magnesium $(\mathrm{mmol} / \mathrm{L})$ & $0.82 \pm 0.05$ & $0.84 \pm 0.05$ & 1.65 & $>0.05$ \\
\hline
\end{tabular}


antioxidant vitamins were studied mostly on asthma and atopic dermatitis. This study is the first study which assesses the levels of antioxidant vitamins and $\mathrm{Mg}$ levels in AR of children.

Vitamin A and active metabolites have a significant importance in the growth, continuity, changes of respiratory tract epithelium, in the repair of the damaged epithelium, and immune system. Additionally, vitamin A includes features such as anti-inflammatory, antiinfective and antioxidant effects. ${ }^{[11,12]}$ As a consequence of increasing number of cells during the repair of damaged tissues and continuing inflammation, a lack of vitamin A may occur. ${ }^{[13]}$ On respiratory syncytial virus and measles infections, there is evidence of lack of vitamin A. ${ }^{[13]}$ These findings support the argument that the vitamin A consumption of tissues increases to repair mucosal epithelium which is damaged by the illness together with inflammation, and to prevent the oxidative damage, so a lack of vitamin A occurs. ${ }^{[13-15]}$ There are only few studies showing relationship between allergic illnesses and vitamin A. Moreover, they include quite limited number of patients with asthma and rhino-sinusitis. ${ }^{[12,15,16]}$ There are also several studies exhibiting normal vitamin A levels and some others exhibiting low vitamin A levels. ${ }^{[1,12,15,16]}$ Kompauer et al. ${ }^{[17]}$ showed low vitamin A level in the adults with AR. According to the literature search of the last ten years on children, there is no study on the relationship between AR and vitamin A level. In this study, vitamin A level of children with AR was significantly lower than control group. This finding supports the argument that, the consumption of vitamin A gets higher to minimize the epithelium and tissue damage due to the oxidative stress generated during inflammation process of allergic rhinitis attacks and to provide a suitable condition to regenerate epithelium cells. ${ }^{[13-15]}$

Ascorbic acid is an antioxidant vitamin which is physiologically available in respiratory tracts. As an antioxidant, it may cause a reduction of negative effects caused by oxidative attack on tissues during inflammation. In many studies, it is evident that vitamin $C$ application has high beneficial effects in case of bronchial hyperreactivity. Podoshin et al. ${ }^{[18]}$ showed that vitamin $\mathrm{C}$ reinforcement reduced the symptoms in $74 \%$. On the other hand, vitamin $C$ levels of adult AR patients were found quite normal in the study of Kompauer et al. ${ }^{[17]} \mathrm{In}$ another study on children with asthma, it was shown that the reduction in vitamin $C$ causes and increases the risk of asthma. Kalayc1 et al. ${ }^{[15]}$ showed that children with asthma had lower level of ascorbic acid when comparing with healthy children in the cycle of remission. In our study, there was no difference in vitamin $C$ levels between the AR and control groups. It was coherent with the findings of Kompauer et al. ${ }^{[17]}$

Vitamin E is a significant antioxidant which dissolves in lubricant and presents in tocopherol structure which protects the polyunsaturated fatty acids on mem- brane structure against lipid peroxidation. ${ }^{[19]}$ Montaño Velázquez et al. ${ }^{[19]}$ applied vitamin $\mathrm{E}$ to a group of patients and placebo to another group in addition to the antihistaminic and sympathomimetic drug treatment. They reported no vitamin $\mathrm{E}$ application effect on nasal symptoms of patients with allergic rhinitis. Kompauer et al. ${ }^{[17]}$ found that serum vitamin E level of adults with AR was in normal range. ${ }^{[17]}$ Shahar et al. ${ }^{[20]}$ did not determine any significant difference on nasal symptom scores after vitamin $\mathrm{E}$ reinforcement on patients with seasonal allergic rhinitis. Vitamin E levels of our study were coherent with the other studies. Although the vitamin E levels were higher in the control group, there was no statistically significant difference.

Magnesium functions as a co-factor on enzymatic reactions which play a role on energy metabolism. Tiny quantity of magnesium is needed for the structural compositions of antioxidative enzymes and it has an indirect antioxidant effect. So with this characteristic it has the antioxidant effect indirectly. Magnesium has a significant important role in inflammation by growing up and reproducing cells, and presentation in membrane structure. ${ }^{[11,21]}$ There is no study on magnesium levels of children with AR. Vural et al. ${ }^{[22]}$ did not see any difference on magnesium levels of patients with asthma and control groups. Also we did not find a significant difference in average serum magnesium levels of children with AR and control group statistically.

In our study, although vitamin A level of the study group was significantly lower than the control group, there was no significant difference in vitamin C, vitamin $\mathrm{E}$ and magnesium levels. We think that the smallness of the inflammation area on nasal part does not cause a reduction in these materials because the subject patient group has allergic rhinitis. However, we also think that the level of vitamin A gets significantly lower because vitamin A functions as antioxidant on inflammatory area as well as epithelium regeneration and reproduction.

Some of the available studies show that the vitamin A may be efficient for the treatment of AR. However, there is no certain treatment of allergic rhinitis, today. In terms of clinical findings, it is quite reasonable to use antioxidant vitamin treatment in addition to the present treatments. Especially it is a necessity to investigate antioxidant vitamins in intermediate and severe allergic rhinitis cases.

In conclusion, the findings of antioxidant vitamins and $\mathrm{Mg}$ levels of our investigation contributes to the current data. We think that it will be better to study as double-blind placebo control which also includes treatment conclusions on the number of participants. Considering the pathogenesis of AR which has no certain treatment, more detailed information on degree of utility of antioxidant vitamin reinforcement can be obtained under the control of clinical findings. 


\section{REFERENCES}

1. Sly RM. Changing prevalence of allergic rhinitis and asthma. Ann Allergy Asthma Immunol 1999;82:233-48.

2. Skoner DP. Allergic rhinitis: definition, epidemiology, pathophysiology, detection, and diagnosis. J Allergy Clin Immunol 2001;108(1 Suppl):S2-8.

3. Bolzán AD, Bianchi MS, Bianchi NO. Superoxide dismutase, catalase and glutathione peroxidase activities in human blood: influence of sex, age and cigarette smoking. Clin Biochem 1997;30:449-54.

4. Diplock AT. Antioxidant nutrients and disease prevention: an overview. Am J Clin Nutr 1991;53(1 Suppl):189S-193S.

5. Ratnam DV, Ankola DD, Bhardwaj V, Sahana DK, Kumar MN. Role of antioxidants in prophylaxis and therapy: A pharmaceutical perspective. J Control Release 2006;113:189-207.

6. Di Mascio P, Devasagayam TP, Kaiser S, Sies H. Carotenoids, tocopherols and thiols as biological singlet molecular oxygen quenchers. Biochem Soc Trans 1990;18:1054-6.

7. Bousquet J, Van Cauwenberge P, Khaltaev N; Aria Workshop Group; World Health Organization. Allergic rhinitis and its impact on asthma. J Allergy Clin Immunol 2001;108(5 Suppl):S147-334.

8. Meltzer EO. Allergic rhinitis: managing the pediatric spectrum. Allergy Asthma Proc 2006;27:2-8.

9. Barnes PJ. Reactive oxygen species and airway inflammation. Free Radic Biol Med 1990;9:235-43.

10. van Asbeck BS, Hoidal J, Vercellotti GM, Schwartz BA, Moldow CF, Jacob HS. Protection against lethal hyperoxia by tracheal insufflation of erythrocytes: role of red cell glutathione. Science 1985;227:756-9.

11. Unal M, Tamer L, Pata YS, Kilic S, Degirmenci U, Akbaş $Y$, et al. Serum levels of antioxidant vitamins, copper, zinc and magnesium in children with chronic rhinosinusitis. J Trace Elem Med Biol 2004;18:189-92.
12. Arora P, Kumar V, Batra S. Vitamin A status in children with asthma. Pediatr Allergy Immunol 2002;13:223-6.

13. Shoseyov D, Bibi H, Biesalski H, Reifen R. Repeated allergen challenge in rats increases vitamin A consumption. Chest 2002;122:1407-11.

14. Cser MA, Majchrzak D, Rust P, Sziklai-László I, Kovács I, Bocskai E, et al. Serum carotenoid and retinol levels during childhood infections. Ann Nutr Metab 2004;48:156-62.

15. Kalayci O, Besler T, Kilinç K, Sekerel BE, Saraçlar Y. Serum levels of antioxidant vitamins (alpha tocopherol, beta carotene, and ascorbic acid) in children with bronchial asthma. Turk J Pediatr 2000;42:17-21.

16. Harik-Khan RI, Muller DC, Wise RA. Serum vitamin levels and the risk of asthma in children. Am J Epidemiol 2004;159:351-7.

17. Kompauer I, Heinrich J, Wolfram G, Linseisen J. Association of carotenoids, tocopherols and vitamin $\mathrm{C}$ in plasma with allergic rhinitis and allergic sensitisation in adults. Public Health Nutr 2006;9:472-9.

18. Podoshin L, Gertner R, Fradis M. Treatment of perennial allergic rhinitis with ascorbic acid solution. Ear Nose Throat J 1991;70:54-5.

19. Montaño Velázquez BB, Jáuregui-Renaud K, Bañuelos Arias Adel C, Ayala JC, Martínez MD, Campillo Navarrete R, et al. Vitamin $\mathrm{E}$ effects on nasal symptoms and serum specific IgE levels in patients with perennial allergic rhinitis. Ann Allergy Asthma Immunol 2006;96:45-50.

20. Shahar E, Hassoun G, Pollack S. Effect of vitamin E supplementation on the regular treatment of seasonal allergic rhinitis. Ann Allergy Asthma Immunol 2004;92:654-8.

21. Swain R, Kaplan-Machlis B. Magnesium for the next millennium. South Med J 1999;92:1040-7.

22. Vural H, Uzun K, Uz E, Koçyigit A, Cigli A, Akyol O. Concentrations of copper, zinc and various elements in serum of patients with bronchial asthma. J Trace Elem Med Biol 2000;14:88-91. 